\title{
Exchange Rate Volatility and Domestic Consumption: A Comparative Study of Developed, Developing and Emerging Economies
}

\author{
Muhammad Zubair Chishti (Corresponding author) \\ Quaid I Azam University Islamabad, Pakistan \\ E-mail: chishtimz9@gmail.com \\ Hafiz Syed Muhammad Azeem \\ Research Officer at Ministry of Finance, Pakistan
}

Farrukh Mahmood

Pakistan Institute of Development Economics, Islamabad, Pakistan

Adeel Ahmed Sheikh

Pakistan Institute of Development Economics, Islamabad, Pakistan

Received: August 9, 2019 Accepted: September 16, 2019 Published: September 25, 2019

doi:10.5296/ijafr.v9i3.15248

URL: https://doi.org/10.5296/ijafr.v9i3.15248

\begin{abstract}
The current study endeavors to explore the effects of oscillations in the exchange rate on the household aggregate consumption of developed, emerging, and developing economies, employing the panel data from 1995 to 2017. To select an appropriate panel data estimation technique, we apply Brush-Pagan \& Hausman Tests for each set of chosen economies. Further, our study deduces that, in the case of developed economies, the oscillations in the exchange rate, significantly, affect the domestic consumption, supporting Alexander's (1952) conjecture. However, in the case of emerging and developing economies, aggregate consumption does not respond to the exchange rate volatility.
\end{abstract}

Keywords: Volatile exchange rate, Domestic consumption, Developing economies, Panel data analysis 


\section{Introduction}

Among the four components of GDP concerning expenditure-based approach, consumption is the most stable and substantial element (Bahmani-Oskooee et al. 2015). On average, in every economy, $60-70 \%$ of domestically produced goods are purchased and consumed by domestic residents. Further, consumption is the beginning, as well as the ending of all economic activities (Bahmani-Oskooee and $\mathrm{Xi}, 2012$ ). It is only the consumption, which gives the primary thrust to production (Campbell \& Mankiw, 1989; Saha \& Zhang, 2013).Moreover, the role of household aggregate consumption in the process of a country's economic growth is vital since it defines the standard of living of inhabitants, while the living standard defines the economic status of a country (Murase, 2013). Therefore, it is imperative for economists and the policymakers to understand and to identify the determinants of consumption which can encourage and curtail the economics activities during the recessionary and inflationary times respectively (Hamano, 2013).

Further, traditional determinants of consumption such as income and interest rate have received enough attention in the literature, and most of the studies argued that income and interest rate are the key determinants of consumption (Hamano, 2013). A few reviews explained that inflation is also the determinant of consumption, as inflation can affect the level of consumption (Kugler, 1985; Villagomez, 1994).

Moreover, with the trade openness and the globalization, every country is engaged with international trade to gain the benefits from global markets (Khan \& Syed, 2014). Therefore, the exchange rate becomes as a prime factor which affects not only country's trade flows but also other macroeconomic variables such as GDP, interest rate, inflation rate, investment, and domestic consumption (Auboin \& Ruta, 2011). Therefore, the exchange rate also became the determinant of domestic consumption.

About sixty years ago, Alexander (1952) was the first one who introduced exchange rate as another determinant of domestic consumption through inflationary effects of currency depreciation. According to Alexander (1952), if wages do not fully adjust to inflation, an increase in wages falls behind the inflationary effects of the depreciation of the currency. Consequently, there will be a decrease in the real value of income, and it will affect domestic consumption adversely (Note 1).

After the end of the Bretton Wood system in March 1973, the debates on exchange rate among economists was renewed (Bahmani-Oskooee, 1991). The stability of the exchange rate has become a pressing issue, notably when the fixed exchange rate system changed to the relatively more flexible rates (Obstfeld \& Rogoff, 1998). The volatility of the exchange rate is an important variable that affects the country's key macroeconomic variables such as trade flows, interest rate, inflation, FDI, and domestic consumption (Alexander 1952). Since the exchange rate can affect the domestic consumption, and after the end of the Bretton Wood system, the volatility of the exchange rate also became the determinant of household consumption (Saha, \& Zhang, 2013).

Fluctuations in the exchange rate can affect the consumers and firms negatively through 
different channels. Firstly, consumers and producers don't like the volatility in the exchange rate because it can have adverse effects on their consumption and saving decisions. Because of the uncertainty in the exchange rate, trade may fall, and it will decrease the level of the producer's income at home and a foreign country (Auboin \& Ruta, 2011). As a result, there will be a decline in the level of employment, and finally, it hurts the aggregate consumption. Secondly, producers set their higher prices or may charge risk premium to avoid the risk of future exchange rate uncertainty. Consequently, there will be a decline in aggregate consumption on account of the high prices (Obstfeld \& Rogoff 1998).

Further, the oscillations in exchange rate contribute to uncertainty in inflation, which results in a fall in the real value of householders' income who try to allocate their budget towards expenditures and savings. Consequently, they save more and consume less to preserve their standard consumption level in the future (Siddiqui \& Akhtar, 1999). Also, households may consume more and save less to beat the future expected inflation (Arize \& Malindretos, 1997). Bahmani-Oskooee \& Xi (2012) include the volatility of the exchange rate as another determinant of consumption in the consumption function. Employing the data from Japan, Canada, and the US, they found that the VEX (Note 2) hurts domestic consumption in case of Canada, while it demonstrates positive impact in case of US and Japan, supporting the argument of Obstfeld \& Rogoff 1998.

Only few empirical studies are present in the ample body of the literature on the relationship between the volatile exchange rate and the domestic consumption such as Bahmani-Oskooee and Xi (2011), Bahmani-Oskooee \& Xi, (2012), Bahmani-Oskooee \& Hajilee, (2012), Hamano, (2013), Bahmani-Oskooee, Kutan, \& Xi, (2015). A critical review of the entire body of the concentrated literature brought off on the nexus between VEX and the domestic consumption, divulge that researchers have analysed the relationship regarding only a few economies, considering time-series data. Further, all the previous studies are only about developed and emerging economies which employ ARDL, and GMM approaches. So, this is the first motivation for our research study, which focuses on developed, emerging, and developing economies to investigate the effect of VEX on domestic consumption.

The second motivation for our research is to do penal data analysis, which is not done before yet, according to the best of our knowledge. And the final motivation is to compare the penal data findings of developed, emerging and developing economies, which is also not done before. Hence, due to having many motivational reasons, the current study tends to explore the effects of exchange rate volatility on domestic consumption, considering developed, emerging and developing economies. Moreover, the volatility of the exchange rate in developed, emerging and developing economies for the proposed span time is presented in Figures 1, 2 and 3, respectively, below: 


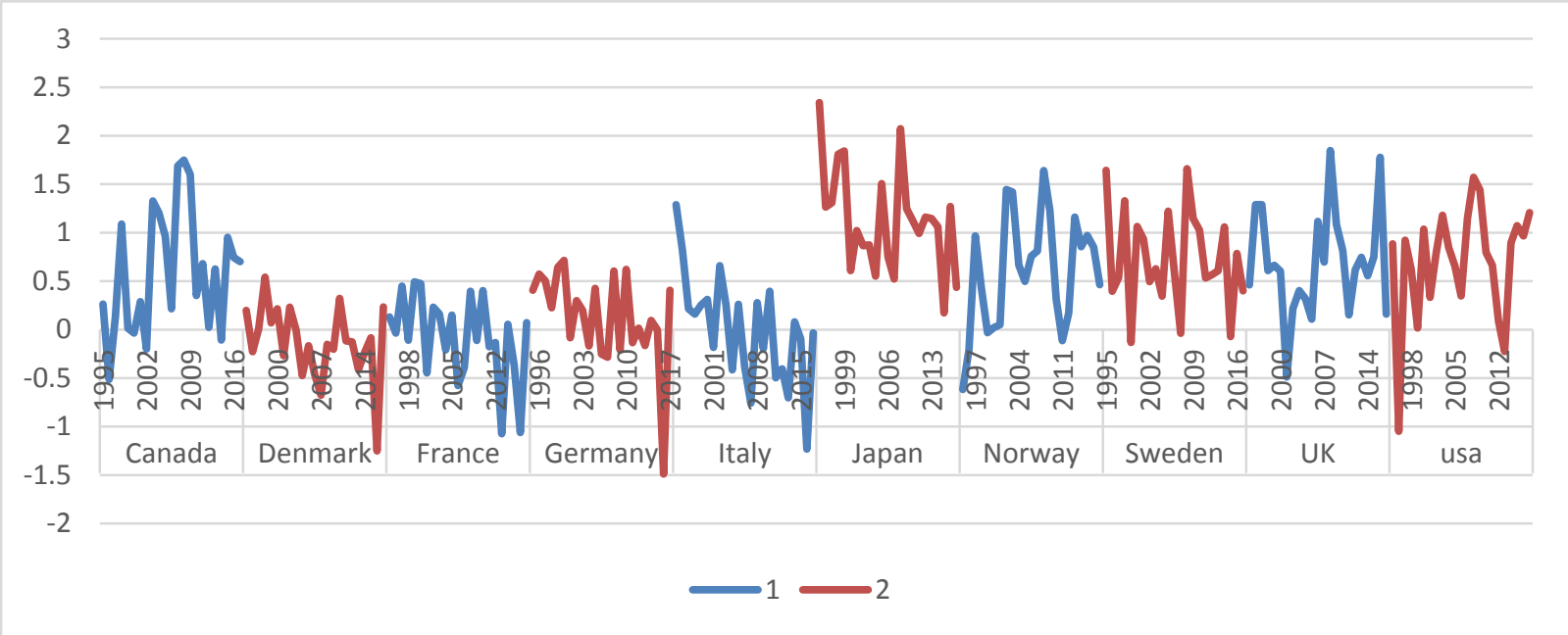

Figure 1. Exchange rate volatility in developed economies

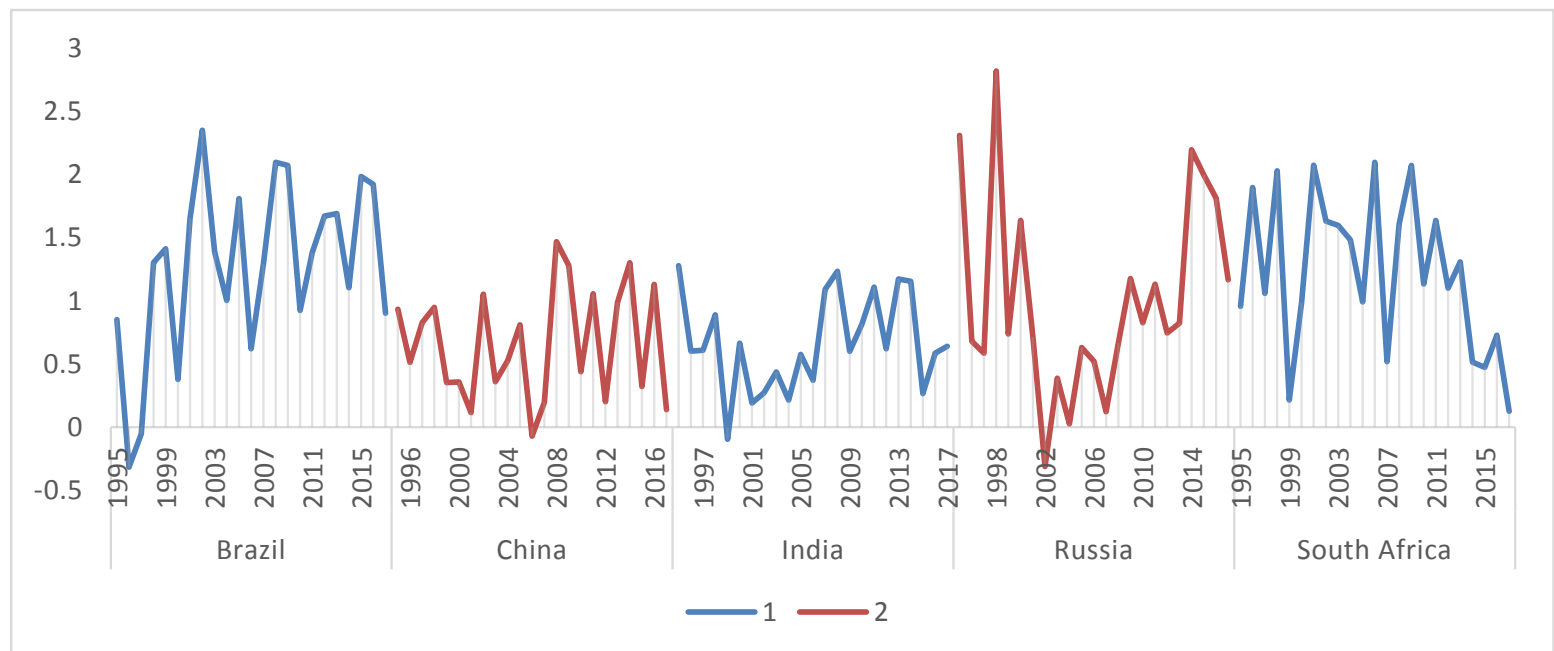

Figure 2. Exchange rate volatility in emerging economies

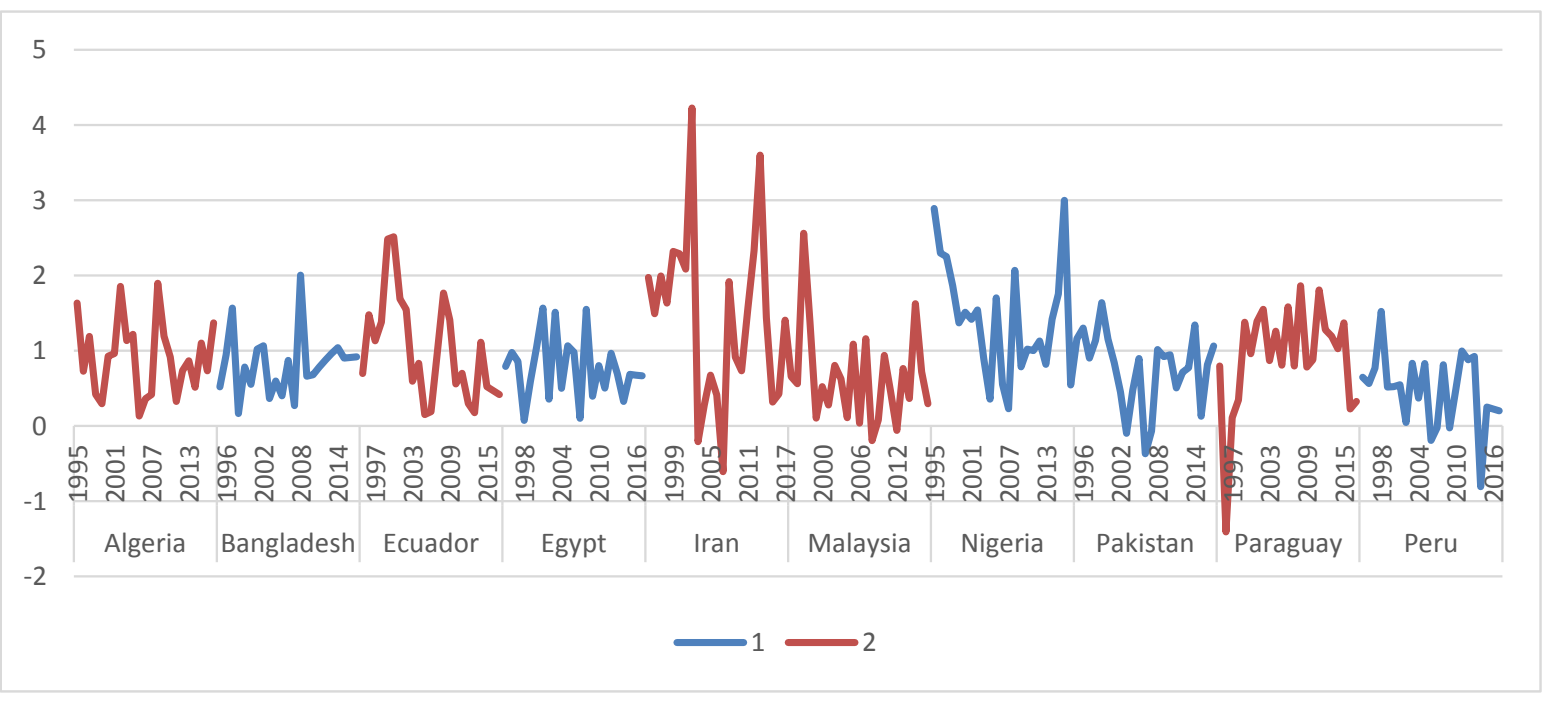

Figure 3. Exchange rate volatility in developing economies 
The remainder of this study is organized as follows:

\section{Literature Review}

As consumption is the prime building block of the demand, it has ever been imperative for researchers to discern its vital determinants. Further, there are a plethora of studies which contain inflation, interest rate, and income as the elements of the consumption. Also, the exchange rate obtained substantial concentration when the fixed exchange rate system was replaced with the floating exchange rate system. Alexander (1952), conceivably, is first who identified the empirical relationship between the consumption and the exchange rate. Moreover, Bahmani-Oskooee (1997), employing the data of 24 economies and making two categories, viz, the economies having high MPC and the economies having low MPC, explored the effects of devaluation in currency on the income inequality. And, the studies concluded that the devaluation in currency results in more income inequality.

Further, taking the data of 18 economies, Bahmani-Oskooee \& Hajilee (2010) investigate the effects of the depreciation of currency on the wages of skilled and unskilled labor and the findings of the study supported Alexander's notion regarding the impacts of exchange rate on the consumption (Note 3). Another study by Bahmani-Oskooee \& Hajilee (2012), using the data of 50 countries, analyze the direct effects of exchange rate on consumption. Applying the bound testing approach propounded by Pesaran, Shin, \& Smith (2001), the study revealed the signification impact of the exchange rate on consumption (Note 4).

Since it is evident by several studies that exchange rate possesses its effects on the consumption, it is conspicuous that its oscillations, through inflationary impact, may also have effects on the consumption. Therefore, Obstfeld \& Rogoff (1998) examine the impacts of volatile exchange rate on household consumption, and the study reveals that the oscillations in EXR affect the consumption adversely through two channels, viz, direct and indirect. Whereas the direct channel is concerned, it demonstrates that the corporations and the households dislike the volatility. Consequently, the fluctuations in EXR their consumption pattern adversely. While the second channel implies that, for minimizing the risk of the volatile exchange rate, the industries have to elevate the price level. Accordingly, the household's consumption plummets on account of the high prices.

According to the best of our knowledge, there are few studies which investigate the implications of the volatile EXR on consumption. As Bahmani-Oskooee \& Xi (2011) examine the impact of the fluctuations in EXR on domestic consumption of 17 selected economies (Note 5), and they employ an ARCH model to capture the volatility. The study concludes that, in the short term, the consumption pattern of 12 economies demonstrates the response and in the long term, the consumption of nine economies shows the response to the volatility. Further, on account of the volatility, the domestic consumption of the 7 economies plummets in the long term.

Again, Bahmani-Oskooee \& Xi (2012), take the quarterly data for the USA, Japan, \& Canada, analyse the volatility and the household's consumption nexus. Applying the bound testing approach by Pesaran et al. (2001), they infer that their findings support the notions by 


\section{Mll Macrothink}

International Journal of Accounting and Financial Reporting

ISSN 2162-3082 2019, Vol. 9, No. 3

Obstfeld \& Rogoff (1998). The study shows that the consumption enhances due to the volatility in the case of Japan and the USA. However, in the case of Canada, the consumption pattern faces the adverse effects on account of the volatility.

In another study, Bahmani-Oskooee et al. (2015), employing quarterly data of 12 emerging economies (Note 6), explore that the volatility has significant effects on the consumption of all emerging economies in the short run. While in the long term, the consumption of only four countries, viz, Bolivia, Bulgaria, Hungary, and Russia respond to the oscillations in EXR. Moreover, Kumar et al. (2019) use the data from 1980 to 2014 to seek the effects of exchange rate volatility on the aggregate consumption of Pakistan. Deploying ARDL approach, the study indicates that the uncertainty in the exchange rate carries harmful repercussions on the domestic consumption in the short and the long run as well.

After reviewing the available studies, we find that all the previous literature includes only developed and emerging economies for empirical analysis. Further, all the previous studies focus only on time series analysis. While the current piece of research takes developed, emerging, and developing economies for comparative analysis. Further, our study employs panel data. Therefore, it worth investigating the effects of volatile exchange rate on domestic consumption, applying the panel data of developing, emerging and developed economies.

\section{Data, Econometric Model \& Technique}

To explore the effects of volatile exchange rate on domestic consumption of developing (Note 7), emerging (Note 8) and developed (Note 9) economies. The current study takes the data for the period of 1995-2017 from the two most authentic and reliable sources. The first source is WDI (Note 10) organized by the World Bank, while another one is IFS (Note 11) of the International Monetary Fund.

Following Alexander (1952) and Bahmani-Oskooee and Xi (2011), our econometric model is:

$$
\operatorname{LnC}_{t}=\beta_{0}+\beta_{1} \operatorname{LnY}_{t}+\beta_{2} \operatorname{Lnr}_{t}+\beta_{3} \operatorname{LnEX}_{t}+\beta_{4} \operatorname{LnVEX}_{t}+\varepsilon_{t}
$$

where $C_{t}, Y_{t}, r_{t}, E X_{t}$ and $V_{E X}$ denote household consumption in real terms, real GDP, interest rate, exchange rate and volatility of EXR respectively, while et represents the error term. Moreover, all variables are in natural logarithmic form.

The equation (1) denotes a time-series model. However, the current study, for panel data analysis, tends to covert the equation (1) into the panel data equation as:

$$
\operatorname{LnC}_{i t}=\beta_{0}+\beta_{1} \operatorname{LnY}_{i t}+\beta_{2} \operatorname{Lnr}_{i t}+\beta_{3} \operatorname{LnEX}_{i t}+\beta_{4} \operatorname{LnVEX}_{i t}+\varepsilon_{i t}
$$

Equation (2) is the cardinal equation of our study, where again $\mathrm{C}_{\mathrm{i}}, \mathrm{Y}_{\mathrm{it}}, \mathrm{r}_{\mathrm{it}}, \mathrm{EX}_{\mathrm{it}}$, and $\mathrm{VEX}$ it (Note 12) denote the same variables, respectively, discussed in equation one.

\subsection{Methodology}

For panel data analysis, the current study tends to employ the following panel data techniques: 


\subsubsection{Pooled OLS Model}

As far as Pooled-OLS model is concerned, it deems the assumption of homogeneity, viz, all the cross-sectional entities are homogeneous regarding their characteristics. Therefore, considering the assumption, the equation of the models can be written as:

$$
\operatorname{LnC}_{i t}=\beta_{0}+\beta_{1 \mathrm{i}}+\beta_{2 \mathrm{i}} \operatorname{LnY}_{\mathrm{it}}+\beta_{3 \mathrm{i}} \operatorname{Lnr}_{\mathrm{it}}+\beta_{4 \mathrm{i}} \operatorname{LnEX}_{\mathrm{it}}+\beta_{5 \mathrm{i}} \operatorname{LnVEX}_{\mathrm{it}}+\varepsilon_{\mathrm{it}}
$$

\subsubsection{Random Effect Model}

Whereas the REM is concerned, to tackle the problem of homogeneity in Pooled-OLS model, REM assumes the reality of heterogeneity and incorporates it in the equation. Further, the model deems that covariance between the cross-sectional heterogeneity and the fixed variables are zero. And, the final shape of the RE model which we compute can be written as:

$$
\operatorname{LnC}_{i t}=\beta_{0}+\beta_{1 \mathrm{i}}+\beta_{2 \mathrm{i}} \operatorname{LnY}_{\mathrm{it}}+\beta_{3 \mathrm{i}} \operatorname{Lnr}_{\mathrm{it}}+\beta_{4 \mathrm{i}} \operatorname{LnEX}_{\mathrm{it}}+\beta_{5 \mathrm{i}} \operatorname{LnVEX}_{\mathrm{it}}+\mathrm{v}_{\mathrm{i}}+\mathrm{e}_{\mathrm{it}}
$$

\subsubsection{Fixed Effect Model}

Whereas the fixed effect model is concerned, it tackles both exigencies of homogeneity and covariance, and it considers the cross-sectional heterogeneity and the covariance between independent and error term. Further, the final form of the model can be written as:

$$
\operatorname{LnC}_{i t}=\beta_{1 \mathrm{i}}+\beta_{2} \operatorname{LnY}_{i t}+\beta_{3} \operatorname{Lnr}_{i t}+\beta_{4} \operatorname{LnEX}_{i t}+\beta_{5} \operatorname{LnVEX}_{i t}+\varepsilon_{i t}
$$

In a nutshell, we compute our prime equation (2), employing all three models, i.e., Pooled OLS, REM, and FEM.

To get empirical findings for emerging, developed and developing countries, we compute equation (2), employing traditional panel data estimation techniques, i.e., Pooled OLS, Random Effect, and Fixed Effect Models. Moreover, the choice of these three models is carried out by using two different model specification tests. The first one is Brush-Pagan LM test by Breusch \& Pagan, (1980), we apply to decide whether the POLS is more appropriate or REM. While the second one is Hausman Model specification test by Hausman, \& McFadden, (1981), we employ to determine whether FEM is optimal or REM.

In the case of emerging countries, the null hypothesis of Brush-Pagan test is accepted and suggests that Pooled OLS is more appropriate than the Random Effect model. However, according to the econometric theory (Note 13), POLS technique is only applicable when there is homogeneity across cross-section units. On the contrary, there are five emerging economies: Brazil, Russia, India, China, and South Africa and their economic indicators, economic structure, living standard, etc. are different from each other. Consequently, heterogeneity is observed in the panel of these countries as the graph presented in conclusion indicates that there is a difference in the mean of different series. Moreover, the null hypothesis of Hausman Model specification test is rejected. Thus, it suggests that FEM is more appropriate than the REM in case of emerging economies.

Whereas the developed and the developing countries are concerned, the null hypothesis of B-P test is rejected and suggests that the REM is more appropriate than POLS. Further, the 


\section{Ml Macrothink}

International Journal of Accounting and Financial Reporting

ISSN 2162-3082

2019, Vol. 9, No. 3

null hypothesis of Hausman is accepted in favour of REM. Thus, the final selected model through these two tests is the Random Effect model in case of both developed and developing countries.

\section{Results}

After the selection of appropriate techniques for computation through econometric tests, we discuss our empirical findings. Taking the developed economies firstly, Table 1 shows the empirical results based on POLS, FEM and REM. Keep in mind that our focused results are given in the column of Random Effect model, as it is the final selected model through both model specification tests. Further, Table 1 shows the findings.

Table 1. Results for selected developed economies

\begin{tabular}{llll}
\hline Independent Variables & \multicolumn{2}{l}{ Estimation technique } & FE \\
\cline { 2 - 4 } & \multicolumn{1}{l}{ Pooled OLS } & RE & 1.112 \\
Real GDP & 1.105 & 1.112 & $(0.000)^{* * *}$ \\
\hline & $(0.000)^{* * *}$ & $(0.000)^{* * *}$ & 0.008 \\
Interest rate & 0.023 & 0.006 & $(0.197)$ \\
\hline & $(0.000)^{* * *}$ & $(0.388)$ & 0.118 \\
Exchange rate & 0.062 & 0.118 & $(0.000)^{* * *}$ \\
\hline Exchange rate & $(0.131)$ & $(0.036)^{* *}$ & 0.005 \\
Volatility & -0.012 & 0.005 & $(0.095)^{*}$ \\
\hline Intercept & $(0.061)^{*}$ & $(0.091)^{*}$ & -4.764 \\
\hline Cross sections & -3.884 & -4.324 & $(0.000)^{* * *}$ \\
\hline Observations & $(0.000)^{* * *}$ & $(0.000)^{* * *}$ & 10 \\
\hline B-P LM Test & 10 & 10 & 230 \\
\hline p-value & 230 & 230 & \\
\hline
\end{tabular}

\section{Hausman test}

p-value

\subsection{7}

$(0.7954)$

The Values in the parenthesis are P-values.

$*, * *, * * *$ represent significance at $10 \%, 5 \%$ and $1 \%$ respectively. 


\section{Mll Macrothink}

International Journal of Accounting and Financial Reporting

ISSN 2162-3082

2019, Vol. 9, No. 3

Table 1 reveals that the income variable (Real GDP) carries a highly significant and positive coefficient in the case of developed economies, supporting the Keynesian view (Note 14). The results suggest that, if real GDP increases by $1 \%$, then domestic consumption increase by 1.112 percent. Further, interest rate carries a positive but insignificant coefficient which doesn't support the classical view of the interest rate (Note 15). The possible reason is that the interest rate in developed countries is meager, and households of these countries don't give much importance to the interest rate on their consumption pattern or consumption decision. Therefore it has no significant effect on domestic consumption. Also, Alexander's (1952) original idea that currency appreciation increases the aggregate consumption receives support in case of developed countries since the estimated coefficient of the exchange rate is, significantly, positive.

Similarly, the coefficient of our prime variable, viz, the volatile exchange rate estimated with Random effect model has a small positive, but significant effect on domestic consumption again supports the Alexander's (1952) original idea. The result suggests that if the exchange rate volatility appreciates by $1 \%$, it will affect domestic consumption by 0.005 percent positively. The reason of this positive relationship is inflationary effects, as the fluctuations in exchange rate contribute to variations in inflation and make more uncertainty to consumers or households who try to allocate their budget towards consumption and saving. So, the inflationary effects induce the households to consume more today to beat expected inflation in the future.

Whereas the outcomes of emerging economies are concerned, Table 2 shows the empirical results based on POLS, FEM, and REM. Further, our concentrated findings are of the Fixed Effect model, as it is the final selected model verified through both model specification tests.

Table 2. Results for selected emerging economies

\section{Estimation technique}

Independent Variables

Pooled OLS

RE

FE
0.879
0.879
0.867

Real GDP

$(0.000)^{* * *}$

$(0.000)^{* * * *}$

$(0.000)^{* * * *}$

\begin{tabular}{llll}
\hline Interest rate & $\begin{array}{lll}-0.111 \\
(0.000)^{* * *}\end{array}$ & $\begin{array}{l}-0.111 \\
(0.000)^{* * *}\end{array}$ & $\begin{array}{l}-0.053 \\
(0.001)^{* * *}\end{array}$ \\
\hline Exchange rate & 0.319 & 0.319 & 0.275 \\
& $(0.000)^{* * *}$ & $(0.000)^{* * *}$ & $(0.000)^{* * *}$ \\
\hline
\end{tabular}




\begin{tabular}{llll}
\hline Exchange rate $\quad(0.484)$ & $(0.484)$ & $(0.196)$
\end{tabular}

Volatility

\begin{tabular}{llll}
\hline Intercept & $\begin{array}{l}1.040 \\
(0.099)^{*}\end{array}$ & $\begin{array}{l}1.040 \\
(0.096)^{*}\end{array}$ & $\begin{array}{l}1.903 \\
(0.000)^{* * *}\end{array}$ \\
\hline Cross sections & 05 & 05 & 05 \\
\hline Observations & 115 & 115 & 115 \\
\hline B-P LM Test & 0.00 & & \\
p-value & $(1.000)$ & 87.75 & \\
\hline Hausman test & & $(0.000)^{* * *}$ & \\
p-value & & & \\
\hline
\end{tabular}

The Values in the parenthesis are P-values.

$*, * *, * * *$ represent significance at $10 \%, 5 \%$ and $1 \%$ respectively.

Table 2 demonstrates that Real GDP carries a highly significant and positive coefficient, supporting the Keynesian view. The results suggest that, if real GDP increases by $1 \%$, domestic consumption also increases by 0.867 percent. Further, the interest rate affects domestic consumption adversely, showing strong support for the classical view (Bahmani-Oskooee, M., \& Xi, D., 2012). Again, Alexander's (1952) original idea gets support in case of emerging economies since the estimated coefficient of the exchange rate possesses a highly significant effect.

However, the oscillations in exchange have no significant effect on domestic consumption in the case of emerging economies. The possible reason for this result is that most of the imports of emerging countries are non-consumer items, while the exports are consumer items. As a result, the consumption basket of the households of these countries doesn't include the imported consumer goods up to a large extent. Further, the inhabitants tend to consume domestically produced products rather imported. In this way, they don't bother the fluctuations in the exchange rate. Therefore volatility of the exchange rate is likely does not have any significant effect on domestic consumption in case of emerging countries (Note 16).

We are now moving to the findings of developing economies, as Table 3 presents. As both model Brush-Pagan and Hausman model specification tests finalize the REM, we concentrate on the second column of the results. 
Table 3. Results for selected developing economies

\begin{tabular}{llll}
\multirow{2}{*}{ Independent Variables } & \multicolumn{2}{l}{ Estimation technique } & \\
\cline { 2 - 4 } Real GDP & Pooled OLS & RE & FE \\
\hline \multirow{2}{*}{ Interest rate } & 0.910 & 0.927 & 0.945 \\
\hline Exchange rate & $(0.000)^{* * *}$ & $(0.000)^{* * *}$ & $(0.000)^{* * *}$ \\
\hline Exchange & 0.151 & 0.496 & 0.047 \\
Volatility & $(0.000)^{* * *}$ & $(0.007)^{* * *}$ & $(0.009)^{* * *}$ \\
\hline Intercept & -0.114 & -0.009 & -0.004 \\
& $(0.327)$ & $(0.869)$ & $(0.938)$ \\
\hline Cross sections & -0.053 & -0.002 & -0.002 \\
\hline Observations & $(0.174)$ & $(0.671)$ & $(0.543)$ \\
\hline B-P LM Test & 2.081 & 1.985 & 2.054 \\
p-value & $(0.016)^{* *}$ & $(0.044)^{* *}$ & $(0.054)^{*}$ \\
\hline Hausman test & 10 & 10 & 10 \\
p-value & 230 & 230 & 230 \\
\hline
\end{tabular}

The values in the parenthesis are P-values.

$*, * *, * * *$ represent significance at $10 \%, 5 \%$ and $1 \%$ respectively.

Table 3 reflects that Real GDP carries a highly significant and positive impact on domestic consumption in case of developing economies, again, supporting the Keynesian view. Further, the interest rate demonstrates a significant and positive effect, neglecting the classical aspect of the interest rate. The possible reason for this positive relation is when interest rate increases, there is an increase in the supply of deposits in money/capital markets and capital inflow increases. As a result, credit availability increases, and households get more credit/loans to finance their expenditures - consequently, domestic consumption increases.

However, in the case of developing economies, the coefficient of EXR does not satisfy Alexander's argument. Similarly, the volatility of the exchange rate also shows no effect on domestic consumption. The possible reason is that, in developing countries, majority of the people are poor and prefer domestically produced goods as they can't afford imported or luxury goods, so their consumption basket doesn't include the imported goods up to a large extent. 


\section{Macrothink}

Therefore, the VEX show no impact on aggregate demand (Note 17).

\section{Concluding Remarks}

Consumption is deemed as a cornerstone for an economy since, in majority of the economies of the globe, the inhabitants consume 60 to $70 \%$ domestically produced goods. Further, it is the only consumption which motivates the overall production. The economies with a low level of consumption face a sudden fall in production, which leads to a decline in the investment. And, the shrink in investment plummets employment level which tends to cause poor living standard and high unemployment level. Eventually, economic growth depresses. Therefore, the policymakers pay adequate attention to determinants such as interest rate, disposable income, etc. of the consumption to fine-tune the economy.

Further, the trade openness and the globalisation proved that the exchange rate is also a prominent determinant of the consumption. Alexander (1952) was the first who deemed the exchange rate as a determinant of the aggregate consumption. Moreover, a few studies also explored the oscillations in the exchange rate, and the consumption nexus as the volatility through inflation effect may affect consumption positively or negatively.

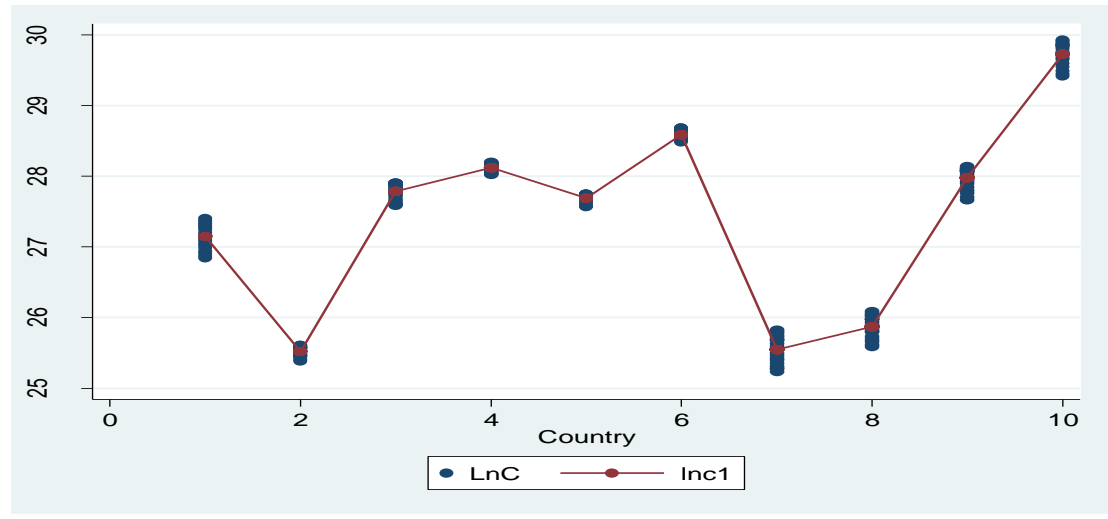

Figure 4. The cross-sectional heterogeneity among developed countries

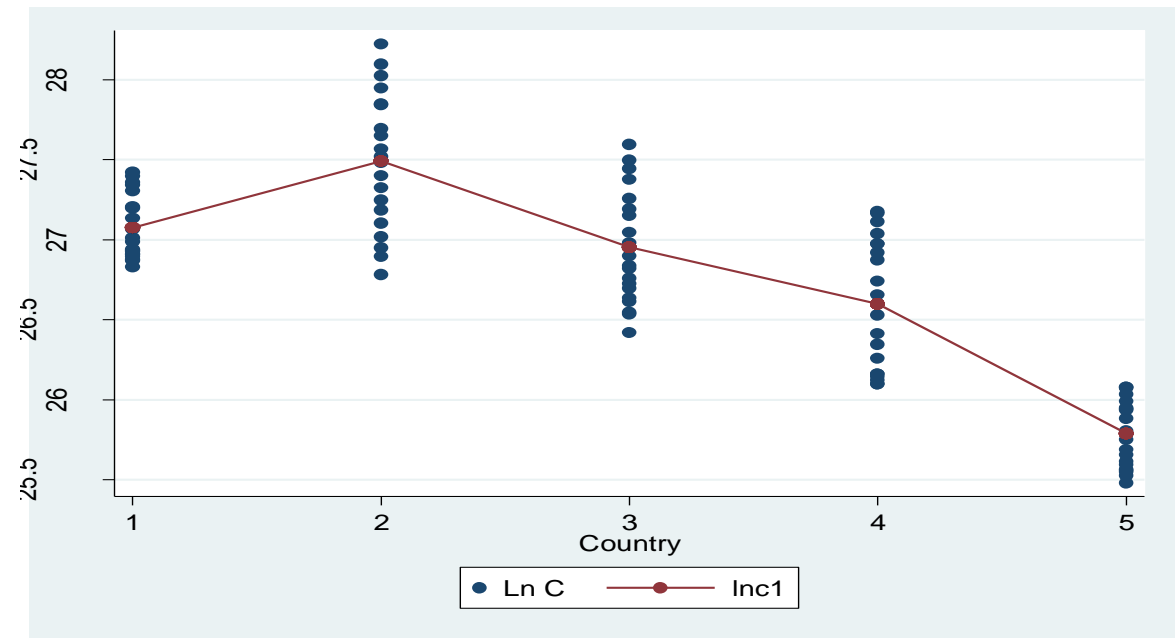

Figure 5. The cross-sectional heterogeneity among emerging countries 


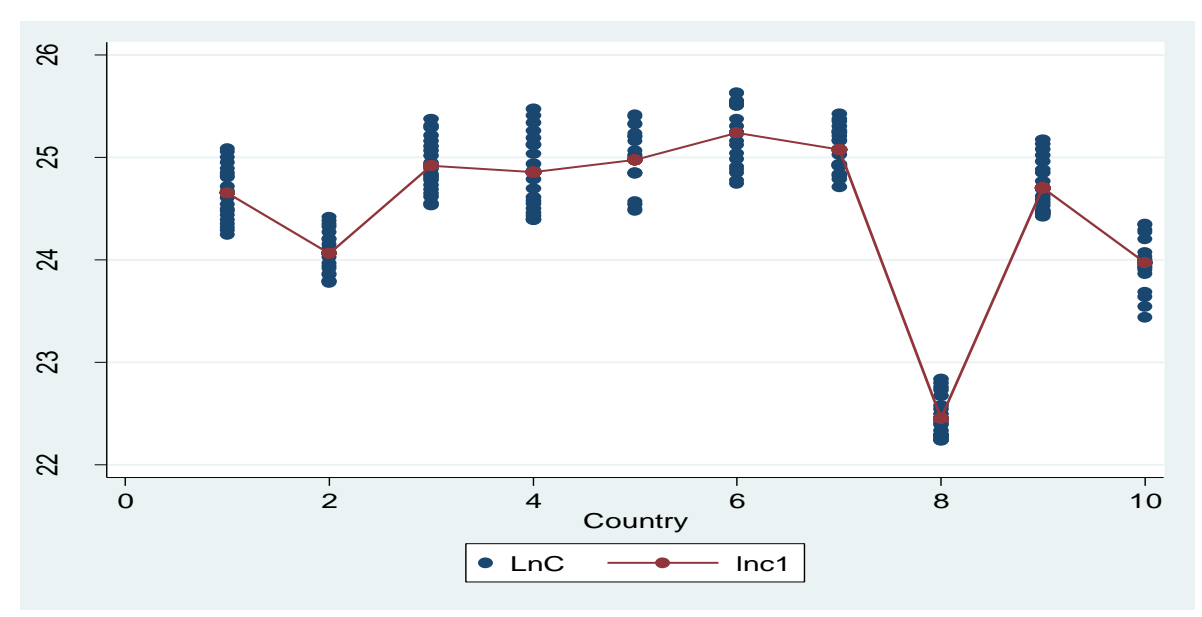

Figure 6. The cross-sectional heterogeneity among developing countries

The available literature focuses only on developed economies to investigate the effects of exchange rate volatility on consumption. Besides, there is not a single study which presents the comparative analysis of developed, developing \& emerging economies. To fulfill this gap in the literature, our study explores the effects of volatile exchange rate on the aggregate consumption of developed, developing \& emerging economies. Based on empirical findings, our study gathers, using the data for the period of 1995-2017, that the exchange rate possesses a significant impact on domestic consumption in case of selected developed and developing economies. However, in the case of developing countries, our study does not support Alexander's (1952) conjecture. Whereas the response of consumption to the volatility is concerned, fascinatingly, only the findings of developed economies demonstrate significant impact. However, in the case of emerging and developing economies, our study shows no significant effect.

For economists and the policymakers, the current study recommends substantial implications based on empirical findings. Firstly, the policymakers of developed economies must keep serious concern with monetary or fiscal policy Since the exchange rate, and its fluctuations show a significant impact on consumption through uncertain inflation. Consequently, consumers are forced to raise consumption during the high-interest rate. Secondly, to fine-tune the economy, the policymakers should consider the interest rate in order to control the volatile exchange rate. Lastly, the impact of the volatility is negative; however, insignificant in case of developing economies, the policymakers should concern with appropriate fiscal or monetary policy for the future. Also, our study concludes that, in the case of most economies, Alexander's (1952) conjecture holds.

\section{References}

Alexander, S. S. (1952). Effects of a Devaluation on a Trade Balance. Staff Papers-International Monetary Fund, 2(2), 263-278.

Arize, A. C., \& Malindretos, J. (1997). Effects of exchange-rate variability on inflation variability: some additional evidence. Applied Economics Letters, 4(7), 453-457. 
Auboin, M., \& Ruta, M. (2011). The relationship between exchange rates and international trade: a review of economic literature.

Bahmani-Oskooee, M. (1991). Effects of exchange rate variability on inflation variability. World Development, 19(6), 729-733.

Bahmani-Oskooee, M. (1997). Effects of devaluation on income distribution. Applied Economics Letters, 4(5), 321-323.

Bahmani-Oskooee, M., \& Hajilee, M. (2012). On the Relation between Currency Depreciation and Domestic Consumption-La relazione tra deprezzamento della valuta e consumi interni. Economia Internazionale/International Economics, 65(4), 503-512.

Bahmani-Oskooee, M., \& Hajilee, M. (2013). Exchange rate volatility and its impact on domestic investment. Research in Economics, 67(1), 1-12.

Bahmani-Oskooee, M., \& Hegerty, S. W. (2008). Exchange-rate risk and US-Japan trade: Evidence from industry level data. Journal of the Japanese and International Economies, 22(4), 518-534.

Bahmani-Oskooee, M., \& Xi, D. (2011). Exchange rate volatility and domestic consumption: a multicountry analysis. Journal of Post Keynesian Economics, 34(2), 319-330.

Bahmani-Oskooee, M., \& Xi, D. (2012). Exchange rate volatility and domestic consumption: Evidence from Japan. Economic Systems, 36(2), 326-335.

Bahmani-Oskooee, M., Kutan, A. M., \& Xi, D. (2015). Does exchange rate volatility hurt domestic consumption? Evidence from emerging economies. International Economics, 144, 53-65.

Bakkeli, N. Z. (2016). Income inequality and health in China: A panel data analysis. Social Science \& Medicine, 157, 39-47.

Breusch, T. S., \& Pagan, A. R. (1980). The Lagrange multiplier test and its applications to model specification in econometrics. The Review of Economic Studies, 47(1), 239-253.

Campbell, J. Y., \& Mankiw, N. G. (1989). Consumption, income and interest rates: Reinterpreting the time series evidence. In NBER Macroeconomics Annual 1989 (Volume 4, pp. 185-246). MIT Press.

Hamano, M. (2013). The consumption-real exchange rate anomaly with extensive margins. Journal of International Money and Finance, 36, 26-46.

Hausman, J. A., \& McFadden, D. (1981). Specification tests for the multinomial logit model.

Khan, A. J., Azim, P., \& Syed, S. H. (2014). The Impact of Exchange Rate Volatility on Trade. The Lahore Journal of Economics, 19(1), Summer, 31-66.

Kugler, P. (1985). Autoregressive modelling of consumption, income, inflation and interest rate data: A multicountry study. Empirical Economics, 10(1), 37-50. 


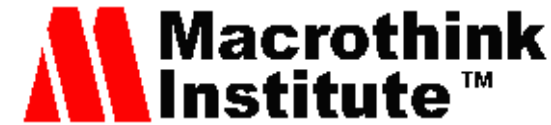

International Journal of Accounting and Financial Reporting

ISSN 2162-3082

2019, Vol. 9, No. 3

Kumar, A., Bhutto, N. A., Mangrio, K. A., \& Kalhoro, M. R. (2019). Impact of external debt and exchange rate volatility on domestic consumption. New evidence from Pakistan. Cogent Economics \& Finance, 7(1), 1568656.

Murase, K. (2013). Asymmetric effects of the exchange rate on domestic corporate goods prices. Japan and the World Economy, 25, 80-89.

Obstfeld, M., \& Rogoff, K. (1998). Risk and exchange rates (No. w6694). National bureau of economic research.

Pesaran, M. H., Shin, Y., \& Smith, R. J. (2001). Bounds testing approaches to the analysis of level relationships. Journal of Applied Econometrics, 16(3), 289-326.

Saha, S., \& Zhang, Z. (2013). Do exchange rates affect consumer prices? A comparative analysis for Australia, China and India. Mathematics and Computers in Simulation, 93, 128-138.

Siddiqui, R., \& Akhtar, N. (1999). The impact of changes in exchange rate on prices: a case study of Pakistan. The Pakistan Development Review, 1059-1066.

Villagómez, F. A. (1994). Aggregate consumption, interest rates and inflation in LDCs: an error correction model. The Journal of Development Studies, 31(1), 157-178.

\section{Notes}

Note 1. In order to confirm the Alexander's conjecture, Bahmani-Oskooee and Hajilee (2012) include the exchange rate in consumption function as another determinant of domestic consumption. Computing the model for 50 countries, they found the short-run effect of depreciation of currency on consumption in 37 countries, while the long-run effect was found only in 24 economies, supporting supports the Alexander's conjecture.

Note 2. Stands for "volatile exchange rate".

Note 3. Since Bahmani-Oskooee \& Hajilee (2010) concluded that the wages of unskilled labor in the six economies plummet on the account of the depreciation.

Note 4. The study deduced the significant impact of EXR on consumption in 37 economies in the short run and in 24 countries in the long run.

Note 5. These 17 economies are: Ireland, Greece, Germany, France, Belgium, Austria, Australia, Canada, USA, UK, Switzerland, Singapore, Norway, Sweden, New Zealand, Korea, \& Japan.

Note 6. These emerging economies are: Chile, Bolivia, Hungry, Armenia, Colombia, South Africa, Malaysia, Bulgaria, Poland, Czech Republic, Russia, and Philippine.

Note 7. Pakistan, Bangladesh, Iran, Egypt, Nigeria, Malaysia, Paraguay, Peru, Algeria, \& Ecuador. 


\section{Macrothink \\ International Journal of Accounting and Financial Reporting \\ ISSN 2162-3082 \\ 2019, Vol. 9, No. 3}

Note 8. Brazil, Russia, India, China, \& South Africa.

Note 9. Canada, Denmark, France, Italy, Germany, Japan, Norway, Sweden, United Kingdom, \& United States.

Note 10. Word Development Indicators.

Note 11. International Financial Statistics.

Note 12. The volatility is computed through the "Standard Deviation of the 12 Months" (Bahmani-Oskooee and Xi, 2011).

Note 13. As pointed out by Gujarati, pp: 594.

Note 14. As pointed out by Bahmani-Oskooee, \& Xi, (2012).

Note 15. The possible reason of this result is that interest rate in developed countries is very low and households of these countries don't give much importance to interest rate on their consumption pattern or consumption decision.

Note 16. Bahmani-Oskooee et al. (2015) also explored the same findings in case of emerging economies.

Note 17. Another possible reason is that the major imports of developing countries are non-consumer goods such as heavy machinery, military equipments, air crafts etc. So the consumption basket of these countries doesn't includes the imported consumer goods. Thus, the fluctuations in exchange rate don't affect their consumption pattern.

\section{Copyright Disclaimer}

Copyright for this article is retained by the author(s), with first publication rights granted to the journal.

This is an open-access article distributed under the terms and conditions of the Creative Commons Attribution license (http://creativecommons.org/licenses/by/4.0/) 